\title{
Effects of online Christian self-disclosure on impression formation
}

\author{
Piotr S. Bobkowski \\ Sriram Kalyanaraman \\ University of North Carolina at Chapel Hill
}

Submitted for publication in the Journal for the Scientific Study of Religion

\begin{abstract}
Increased reliance on social media to initiate and maintain relationships warrants research that investigates how religion affects Internet-based impressions. Evidence suggests that some Christians avoid identifying religiously online to prevent unfavorable evaluations by those with whom they interact on the Internet. This experiment examined the effects of online Christian disclosure. Respondents $(N=233)$ viewed a fictional social networking profile containing one of three levels of Christian disclosure frequency: none, nominal, and extensive. There was conflicting evidence for a direct association between Christian disclosure and impressions. Regardless of disclosure level, however, religious respondents rated profile owners as more likeable and with less negative stereotypes, than less religious respondents. Most notably, respondent religiosity moderated impressions. The least religious respondents tended to rate the extensively disclosing Christian as least romantically desirable and as most representative of negative stereotypes. The most religious respondents rated this individual as most likeable and as most romantically desirable. Effects of nominal disclosure showed little association with respondent religiosity, suggesting that nominal disclosure may constitute a socially acceptable
\end{abstract}


level of online Christian disclosure. Respondents made few distinctions between nondisclosure and nominal disclosure, and Christian identity tended to be assumed when not disclosed, which also illustrated the low relevance of Christian nominal disclosure as an identity marker.

At a time when an increasing number of Internet users initiate and maintain relationships via social media (e.g., blogs, dating services, social networking websites), it is important to examine the extent to which religious self-disclosure enhances or inhibits communication within these Internet venues.

This study focuses on the effects of Christian self-disclosure in social networking websites. Social networking users, in general, tend not to disclose religious identities in their personal profiles. Studies show that, among college students in the United States, $21 \%$ present a religion on Facebook (Pempek, Yermolayeva, and Calvert 2009). On MySpace, 45\% of the profiles display a "Religion" field (Liu 2007). Christians seem underrepresented among MySpace users: 26\% display a Christian label ("Catholic," "Christian-other," or "Protestant”) (Liu 2007).

Research findings show that some Christians mute their religious identities in their social networking profiles to avoid unfavorable evaluations by fellow website users (Bobkowski 2008). Studies focused on interpersonal impressions in offline contexts have suggested that Christian identification elicits negative reactions (Hyers and Hyers, 2008; Kinnaman and Lyons, 2002). In order to examine whether personal Christian content affects online communication, this study measured the effect of Christian self-disclosure in a social networking profile on impression formation. 


\section{Conceptual background}

Levels of Christian self-disclosure

Self-disclosure is central to interpersonal relationships (Greene, Derlega, and Mathews 2006). Since religion continues to be a vital force that shapes some people's values and motivates their actions, openness about religion may be collectively and individually beneficial. On a societal level, religious self-disclosure may increase awareness of religious diversity and promote religious literacy (e.g., Prothero 2007). On an individual level, self-disclosure of sensitive information has been linked to increased social support and enhanced self-worth (Greene, Derlega, and Mathews 2006), suggesting that religious self-disclosure may be beneficial for psychological wellbeing.

Studies examine the category and frequency of self-disclosure (Altman and Taylor 1973; Wheeless and Grotz 1976). Religion constitutes a distinct disclosure category (Taylor and Altman 1966), as do other personal characteristics such as education, romantic relationships, and interests. Frequency denotes the number of category-specific items communicated within a given disclosure. In the course of a single communication instance, one may disclose something about one's religious affiliation, frequency of attendance at religious services, beliefs about the afterlife, etc. The sum of these items constitutes religious self-disclosure frequency.

Christianity is the self-disclosure category of interest in the present study. Three levels of disclosure frequency are examined: none, nominal, and extensive. Research findings and social networking website features suggest these to be distinct and salient levels of Christian selfdisclosure in contemporary online settings.

Nondisclosure. Many Christians appear not to identify religiously in online profiles (Liu 2007; Pempek, Yermolayeva, and Calvert 2009). This tendency may reflect the privatized nature 
of personal religiosity in the United States and in other postindustrial societies (Berger 1967;

Carter 1993; Casanova 2003). Offline nondisclosure is illustrated in the behavior of teenagers, who tend to "studiously avoid personal expressions of religious specificity" (Smith and Denton 2005:160), and report that their school friends "largely act as if religion is not part of anybody's life" (Smith and Denton 2005:161). Emerging adults, likewise, do not talk about religion with their peers (Smith and Snell 2009:153). The first level of Christian self-disclosure tested in this study reflects the option, practiced by many, not to identify religiously in public nonreligious settings.

Nominal disclosure. Nominal disclosure is limited to the identification of one's religious affiliation. Popular Internet venues (e.g. MySpace, Match.com) facilitate nominal disclosure by providing users with lists of religious labels for display in their profiles. Nominal disclosure is often the limit of emerging adults' discussions about religion (Smith and Snell 2009:153). This disclosure level is also reflective of the nominal religiosity of those who affiliate with a Christian tradition but rarely practice (e.g., Wuthnow 2007). For many Internet users nominal disclosure, the second level of Christian self-disclosure examined here, constitutes a convenient and accurate disclosure option.

Extensive disclosure. The third level of disclosure used in this study reflects a condition that is antithetical to what many Christians desire their religious disclosures to convey. According to Smith and Denton (2005:141), "Many U.S. teens across all religious traditions seem to hold in their minds a negative image of people who are too religious, which they definitely seek to avoid by muting their own religiosity." Interviews with evangelical college students likewise have suggested that some avoid the label "Christian" in constructing their online profiles to prevent being perceived as "too religious" (Bobkowski 2008). The extensive 
disclosure level, therefore, is designed to communicate the identity of an individual who comes across as being really religious, a hypothetical identity that some Christians cite as the antithesis — "the dreaded self" (Markus and Nurius 1986) — against which they position their religious self-disclosures.

Impression formation in offline and online contexts

Early work in computer-mediated communication suggested that computers were impersonal tools incapable of generating interpersonal impressions (e.g., Culnan and Markus 1987). According to more recent perspectives, however, computer users resourcefully harness the limited cues available to them to effectively relate with their communication partners and technologies (Walther and Burgoon 1992; Walther 1996; Postmes, Spears, and Lea 1998; Kalyanaraman and Sundar 2008). Christian identity cues presented in an online profile should, therefore, influence how these profiles' owners are evaluated.

Impressions of online Christian disclosures should parallel, if not exceed, the effects of similar offline disclosures (Postmes, Spears, and Lea 1998; Walther 1996). Studies focusing on impressions in offline contexts indicate that Christians tend to be perceived negatively. Many people in the United States conflate Christianity with conservative Christianity. Perceptions of conservative Christians, in turn, are often negative because conservative Christians are believed to universally subscribe to restrictive positions on social issues such as premarital sex, abortion, and gay rights (Hout and Fischer 2002). According to Barna Group research, young adults who are not born-again Christians view Christians, in general, in negatively stereotypical terms: as anti-homosexual, judgmental, hypocritical, too involved in politics, out of touch with reality, oldfashioned, insensitive to others, boring, not accepting of other faiths, and confusing (Kinnaman and Lyons 2007). Antipathy toward fundamentalist Christians is a motivating factor in political 
behavior (Bolce and De Maio 1999, 2008). Moreover, college students exhibit only moderate sympathy for targets of anti-Christian remarks, which suggests that, "overt criticism and negative judgment of Christians is not viewed as inherently offensive and hints at some level of the social acceptance of such behaviors" (Hyers and Hyers 2008:130). Taken together, these findings suggest that Christian disclosure in an online profile will stimulate negative appraisals.

Young adults' disclosures in online profiles are often carefully tailored to elicit positive evaluations from acquaintances, friends, and potential romantic partners (Manago et al. 2008). Given this concern with a variety of positive impressions in online contexts, this study measured both how non-romantic likeability and romantic desirability were affected by a profile owner's religious disclosures. Further, considering the negative stereotypes that Christian identification is said to elicit (i.e., anti-homosexual, judgmental, hypocritical, etc.), the study evaluated the negative stereotypes that may be associated with religious disclosures.

If the disclosure of Christian identity online leads to negative impressions, then:

H 1: Profile owners who engage in Christian disclosure with greater frequency will be evaluated (a) as less likeable, (b) as less romantically desirable, and (c) with more negative stereotypes, than profile owners who do not engage in Christian disclosure. Online viewers' impressions of profile owners should be further shaped by the viewers' own religiosities. More religious people may be expected to provide more positive assessments of the profile owners, regardless of the level of Christian disclosure presented in these profiles. Researchers conducting survey interviews have rated religious respondents more positively than those who are less religious, suggesting that religious people are "nicer" overall, or at least more cooperative in research settings (Brennan and London 2001; Ellison 1992; Morgan 1983). More generally, those who are more religious have been shown to be more prosocial, or responsive to 
requests for help, than those who are less religious (Batson, Schoenrade, and Ventis 1993;

Saroglou et al. 2005). This tendency to be nicer or helpful may manifest itself in religious viewers' willingness to evaluate more positively all profile owners, no matter how nonreligious or religious these profile owners appear to be. Thus,

H 2: Respondents who are more religious will evaluate profile owners (a) to be more likeable,

(b) to be more romantically desirable, and (c) with less negative stereotypes, than respondents who are less religious.

In addition to the direct effect of respondent religiosity on evaluation, respondents should also evaluate more positively those profile owners with whom they converge religiously. According to social identity theory (Hogg 2006), individuals who share a social identity minimize the differences between them and evaluate one another in a depersonalized fashion that enhances attraction. Conversely, individuals who do not share an identity inflate their differences and tend toward more negative evaluations. Members of Christian denominations evaluate members of other denominations more negatively than members of their own groups (Biela et al. 1993); and believers and nonbelievers perceive each other unfavorably (Kenworthy 2003).

The principle of homophily, which states that people tend to associate with those with whom they share social characteristics (e.g., Byrne 1971; McPherson, Smith-Lovin and Cook 2001), further suggests that respondents will tend to evaluate more positively those with whom they share a religious identity and evaluate less positively those with whom they diverge religiously. Studies have shown consistently that partners' religiosities in engaged and married couples tend to be convergent (Burgess and Wallin 1943; Buss and Barnes 1986).

Although it focuses on the effect of Christian disclosure frequency, this study does not limit its respondent sample to Christians. Both Christians and non-Christians likely comprise 
most Christians' online audiences, and young people in the U.S. of all faith backgrounds, as well as those who do not affiliate with a religious tradition, are said to subscribe to a set of broadly similar religious sentiments (Smith and Denton 2005; Smith and Snell 2009). It is therefore predicted that respondent religiosity, irrespective of respondent affiliation, will moderate the effect of Christian self-disclosure frequency on respondents' perceptions. Accordingly,

H 3: Respondents who are more religious will evaluate profile owners who engage in Christian disclosure with greater frequency (a) to be more likeable, (b) to be more romantically desirable, and (c) with less negative stereotypes; while respondents who are less religious will evaluate profile owners who engage in Christian disclosure with greater frequency (d) to be less likeable, (e) to be less romantically desirable, and (f) with more negative stereotypes.

\section{Method}

\section{Sample and procedure}

Respondents were undergraduate students at a large university in the southern United States who participated in the study in exchange for course credit. Research sessions were held in a university computer lab. An average of eight students attended each session. The study was approved by the university's Institutional Review Board.

In order to mask the research purpose participants were told that they were pilot testing a new social networking website called UBook. After reading and signing an informed consent form, each respondent viewed a series of six web pages on one of the lab's identical computers. Respondents took an average of five minutes to navigate through the six pages, which featured study instructions, a skeleton of the UBook profile design and functions, and the stimulus profile 
of one UBook user. Participation in the study was concluded upon completion of a subsequent paper-and-pencil questionnaire. Respondents were then provided with a debriefing form. Stimulus profile

Each respondent viewed a UBook profile belonging to a fictitious student named Sam Lindley. Because two impression items assessed potential romantic desirability of the profile owner (see Measures, below), female respondents viewed the profile of a male Sam and vice versa.

Since previous studies identified subject visualization to be an important cue affecting impressions of online communication partners (e.g., Tanis and Postmes 2003), half of the sample viewed a profile that featured a photo, and half viewed a profile without a photo. Within each gender, two photo subjects were used in profiles that contained a photo. Photos were solicited from students at other universities; each student granted permission for his/her image to be used in the study. Eighteen photos (nine for each gender) were pilot tested with a student sample $(N=$ 32). For each gender, the two photos with the most neutral means on subject attractiveness were used in the study.

With the exception of Christian disclosure frequency, all identifiers in the stimulus profile were kept constant across the three conditions. The nondisclosure profile contained no references to religion. The nominal disclosure profile contained the line "Religion: Christian." The extensive disclosure profile contained the same line, and an additional 15 statements that referenced Sam's Christian identity. In sum, the nondisclosure profile contained 659 words, while the extensive disclosure profile contained 785 words, $16 \%$ more than the other two profiles. Appendix 1 presents a comparison of the nominal and extensive disclosure conditions. Appendix 2 presents a male, no-photo, extensive disclosure stimulus. 


\section{Measures}

Manipulation check. Three items were used to check that respondents perceived differences in profile owners' Christian disclosures. An open-ended item prompted respondents to identify the profile owner's religion. Responses identifying the profile owner as Christian were coded 1; other responses or no responses were coded 0 . Respondents also indicated their agreement with the statements, "Sam is religious," and "Sam is too religious," using a sevenpoint scale $(1=$ "Strongly disagree" .. 7 = "Strongly agree"). This scale accompanied all subsequent scale-based items.

Respondent religiosity. Respondent religiosity was assessed with the Santa Clara Strength of Religious Faith Questionnaire-Short Form (Plante et al. 2002; Storch et al. 2004a, 2004b). It is composed of five items (e.g., "I look to my faith as providing meaning and purpose in my life") and designed to quantify religiosity "without assuming that the person is religious, or assuming that the person is of a specific religious denomination" (Plante et al. 2002:360). The five items were reliable (Cronbach's $\alpha=.95$ ), with higher scores indicating a higher religiosity.

Impressions of the profile owner. Profile owner likeability was assessed with three statements. Two of these ("I have a positive impression of Sam," "I feel connected to Sam") were adapted from Tanis and Postmes (2003). The third ("I would add Sam as a social networking friend") was included to reflect the social networking context of the stimulus. The items were reliable $(\alpha=.70)$, with higher scores indicating greater likeability.

Romantic desirability of the profile owner was assessed with two items ("I am attracted to Sam," "I would date Sam"), which were highly correlated $(r=.83, p<.001)$, with higher scores indicating greater romantic desirability. The demographic section of the questionnaire included an open-ended item in which respondents were asked to identify their sexual 
orientation. Participants who identified as gay or lesbian were not included in the analysis of the romantic desirability variable.

Negative stereotype was assessed with six items drawn from the Barna Group's research on negative impressions of Christians (Kinnaman and Lyons 2007). The format of each item was "Sam is," followed by one of the six descriptors: antihomosexual, judgmental, hypocritical, out of touch, old-fashioned, insensitive. The items were reliable $(\alpha=.87)$. Higher scores indicated a more negative assessment of the profile owner.

Control measures. Regression models included four control measures, including respondent gender $(0=$ male, $1=$ female $)$, and the profile owner photo/no photo manipulation $(0$ $=$ no photo, $1=$ photo). The variable lengths of the profiles was controlled with an item in which respondents indicated their agreement with the statement that the profile owner was talkative. Respondents' attention to the profile was measured with four subjective attention items (e.g., "I barely looked at the content of the profile," "I was thoroughly focused on the profile") (adapted from Kalyanaraman and Sundar 2006). The items were reliable $(\alpha=.84)$. Higher scores indicated higher profile attention.

\section{Results}

A total of 233 students participated in the study. This sample was $50 \%$ female, $79 \%$ White, $76 \%$ Christian (including 16\% Catholic; in addition to $20 \%$ nonreligious, and 3\% Jewish), and had a mean age of $20.28(S D=.99)$. Respondent religiosity mean was $4.07(S D=$ 1.97). Five male, gay-identified respondents were not included in the analysis of the romantic desirability variable.

Manipulation checks 
Manipulation checks showed that respondents were less likely to identify the nondiscloser to be Christian $(M=.72, S D=.45)$ than either the nominal discloser $(M=.88, S D=$ $.33), t(150)=3.10, p<.001$, or the extensive discloser $(M=.95, S D=.23), t(153)=4.10, p<$ .001 . There was no statistical difference in identifications of nominal and extensive disclosers as Christian, $t(150)=1.45, p=.15$.

Respondents perceived the extensively disclosing Christian to be more religious $(M=$ $6.67, S D=1.00)$ than both the non-discloser $(M=4.21, S D=1.19), t(155)=13.99, p<.001$, and the nominally disclosing Christian $(M=4.21, S D=1.09), t(150)=14.53, p<.001$. There was no difference in respondents' evaluation as religious of the non-discloser and the nominal discloser, $t(155)=.004, p=1.00$.

Respondents were more likely to indicate that the extensively disclosing Christian was "too religious" $(M=3.36, S D=1.98)$ than both the non-discloser $(M=2.35, S D=1.33), t(155)=$ 4.80, $p<.001$, and the nominally disclosing Christian $(M=2.24, S D=1.21), t(150)=5.24, p<$ .001. There was no difference in respondents" evaluation as "too religious" of the non-discloser and the nominally disclosing Christian, $t(155)=.53, p=.59$.

Hypothesis tests

To address the first hypothesis, each of the three dependent measures was regressed on the four control measures and dummy variables for the two disclosure levels (nondisclosure set as the comparison category). Regression models addressing the second hypothesis additionally included respondent religiosity. Models addressing the third hypothesis included the two interaction terms (nominal disclosure $\times$ respondent religiosity, extensive disclosure $\times$ respondent religiosity). Significant interactions were probed to determine (a) which evaluations of disclosure conditions differed across respondent religiosity (i.e., simple slope $\neq 0$ ), and (b) which predicted 
values differed significantly at minimum and maximum values of respondent religiosity (Bonferroni-adjusted $p<.05$ ) (Aiken and West 1991; Irwin and McClelland 2001).

H 1 predicted that Christian self-disclose will be associated negatively with likeability $(M$ $=4.09, S D=1.20)$ and romantic desirability $(M=2.56, S D=1.47)$, and positively with negative stereotype $(M=2.76, S D=1.05)$. Only $\mathrm{H} 1 \mathrm{~b}$ was supported: nominally disclosing profile owners were rated less romantically desirable than those who did not disclose a religious affiliation $(B=$ $-.05, p=.03$ ) (see Table 2, Model 4). Additionally, contradicting the prediction, extensively disclosing profile owners were rated more likeable than non-disclosers $(B=.45, p=.01)$ (see Table 1, Model 1). There was no association between levels of disclosure and negative stereotype (see Table 3, Model 7).

[Table 1 about here]

H 2 predicted that respondent religiosity will be associated positively with likeability and romantic desirability, and negatively with negative stereotype. Regardless of Christian disclosure, more religious respondents rated profile owners as more likeable $(B=.16, p<.001)$ (see Table 1, Model 2), and with less negative stereotype $(B=-.12, p=.001)$ (see Table 3 , Model 8) than less religious respondents. H 2a and 2c were supported. There was no association between respondent religiosity and romantic desirability (see Table 2, Model 5).

H 3 predicted that respondent religiosity will moderate evaluations of the profile owner as likeable, romantically desirable, and negatively stereotyped. For likeability, the interaction between extensive disclosure and respondent religiosity was significant, $(B=.30, p=.001)$. The slope for extensive disclosure was significantly different from zero $(B=.34, p<.001)$, indicating that extensive disclosure increased profile owner likeability among more religious respondents but decreased likeability among less religious respondents (see Figure 1a). Hypotheses 3(a) and 
(d) were supported. The most religious respondents rated the extensively disclosing Christian as significantly more likeable than both the non-discloser and the nominally disclosing Christian. [Figure 1 about here]

For romantic desirability, the interaction between extensive disclosure and respondent religiosity was significant $(B=.37, p=.001)$. The slope for extensive disclosure was significantly different from zero $(B=.29, p=.001)$, indicating that extensive disclosure increased romantic desirability of the profile owner among more religious heterosexual respondents, but decreased romantic desirability among less religious heterosexual respondents (see Figure 1b). This lent support to $\mathrm{H} 3(\mathrm{~b})$ and (e). The least religious respondents rated the extensively disclosing Christian as significantly less romantically desirable than the nondiscloser. The most religious respondents rated the extensively disclosing Christian as significantly more romantically desirable than both the non-discloser and the nominally disclosing Christian.

For the negative stereotype, the interaction between nominal disclosure and respondent religiosity was significant $(B=.20, p=.02)$. The slope for extensive disclosure was significantly different from zero $(B=-.44, p<.001)$, indicating that negative stereotypes decreased among more religious respondents and increased among less religious respondents (see Figure 1c). H 3(c) and (f) were supported. In addition, the slope for nondisclosure was significantly different from zero $(B=-.29, p=.01)$, indicating the same evaluation pattern of the non-discloser. This finding was not predicted. The least religious respondents rated the extensively disclosing Christian with negative stereotypes significantly more than they did the nominally disclosing Christian.

\section{Discussion}




\section{Online self-disclosure risk}

Internet technologies play an increasingly vital role in mediating human relationships. Religious identities presented in personal profiles online are liable to affect Internet users' perceptions of their communication partners and the quality of their subsequent communications.

This study was prompted by observations that many Christians seem not to disclose religiously online and by reports suggesting that some may minimize their Christian disclosures to avoid negative appraisals. The goal was to measure the effect of Christian disclosure frequency on the evaluation of the profile owner, taking into account the religiosity of the profile viewer. Results support the claim that Christian disclosures sometimes generate negative impressions, although the findings also limit generalizations about this effect.

This study's findings are not conclusive with regard to the direct association between Christian disclosure and impression formation. The nominally disclosing Christian was rated as less romantically desirable than the non-discloser, providing evidence for the predicted negative effect of Christian disclosure on impressions. Counter to this prediction, however, the extensively disclosing Christian was rated as more likeable than the non-discloser. In addition, there was no direct effect of Christian disclosure on the negative stereotype. Given these three disparate outcomes, it is evident that Christian disclosures may sometimes directly affect impressions, but only under some evaluation criteria and not necessarily in the negative direction.

More religious Internet users tend to evaluate their communication partners more positively than those who are less religious, regardless of the level of Christian disclosure communicated by these online partners. The more religious were less likely than the less religious to label the profile owners with negative stereotypes. They were also more likely to 
identify profile owners as more likeable, although this effect disappeared once the two interaction terms were introduced (see Table 1, Model 3). Religious respondents did not supply a uniform positive assessment across the three variables, however. There was no association between religiosity and romantic desirability. This suggests that the positive associations between religiosity and the other two variables were not merely the result of religious respondents' acquiescence in a research setting (e.g., Morgan 1983). Overall, Internet users might expect to be perceived more positively, or at least less negatively, regardless of whether they identify as Christian, by those members of their online audiences who are more religious. This study's most consistent finding was that religious identities of online audience members moderate the effect of Christian disclosure on impressions. Christians who disclose their religious identities in their profiles should expect the impressions generated by these disclosures to depend on the religious identities of the people who view their profiles. Only in some cases, particularly when the disclosures are extensive and the audience members are not religious, will these impressions tend to be negative.

The clearest evidence supporting the belief that Christian disclosure leads to negative impressions is found in two instances of the least religious respondents' evaluations: on romantic desirability, when the extensively disclosing Christian tended to be seen as less desirable than the non-discloser (Figure 1b); and on negative stereotype, when the extensively disclosing Christian tended to be seen in more stereotypical terms than the nominally disclosing Christian (Figure 1c). As unambiguous as these findings are, it is also important to note that there were no statistically significant differences in how likeable these least religious respondents perceived the three types of profile owners to be (Figure 1a). Reactions to extensively religious disclosures are not universal but vary, even among similar observers, depending on the evaluation criteria used. 
Meanwhile, there were no statistical differences in how the non-discloser and the nominally disclosing Christian were evaluated by the least religious respondents and by the most religious respondents on any of the three evaluation criteria. Disclosing that one is a Christian appears to be no different than saying nothing about religion in one's profile. It seems that nominal disclosure constitutes a neutral, socially acceptable level of Christian disclosure.

Finally, extensive Christian self-disclosure can boost the evaluation of the profile owner in a positive direction. Among the most religious respondents the extensively disclosing Christian was significantly more likeable, and significantly more romantically desirable, than either the nominally disclosing Christian and the non-discloser (Figure 1a and b). Clearly, by presenting a considerable amount of religious information Christians are likely to elicit substantial affinity among similarly-minded individuals.

A side note about the romantically desirable measure is warranted here. Researchers have long asserted that religious similarity is an important factor in spouse selection (e.g., Burgess and Wallin 1943; Buss and Barnes 1986). Despite the fact that rates of religious intermarriage have been increasing (Sherkat 2004), this study's findings show that religiosity continues to be of considerable importance in evaluations of a potential partner's suitability. Indeed, romantic desirability was the only evaluation variable under which extensive Christian disclosure was perceived significantly differently than other disclosure levels by both the least religious and the most religious respondents.

Consequently, this research suggests that Christians' disclosures of their religious identities in their online profiles will not garner universally negative reactions. There is no conclusive evidence for a direct link between religious disclosure and negative perceptions. The least religious audience members tend to perceive extensively disclosing Christians negatively, 
but very religious audience members tend to view them positively. Nominal disclosure appears to be no different than not saying anything about religion. In fact, in light of the principles of homophily and social identity theory, it may be somewhat unreasonable to expect that Christian self-disclosure would elicit widespread negative reactions from a majority-Christian U.S. audience. Perhaps some Christians' reluctance to self-disclose is grounded more in the rhetoric of the "Christian persecution complex," popularized by some U.S. religious and political leaders in recent years (Castelli 2007), than in actual experiences of negative reactions to online or offline disclosures.

\section{Christian self-disclosure as an impression cue}

The neutral evaluations of nominal Christian disclosure and this study's other somewhat counterintuitive findings illustrate the low relevance of nominal Christianity as an identity marker. More than two-thirds of respondents in the nondisclosure condition thought the profile owner was Christian, and respondents rated as equally religious profile owners in the nondisclosure and nominal disclosure conditions. In addition, evaluations of profile owners were statistically tied across all three disclosure conditions among the least religious for the likeable measure (Figure 1a); and among the most religious for the negative stereotype measure (Figure 1c). As unexpected as these observations might be, they make sense within the general context of American youths' relatively indifferent attitudes toward religion.

Young people in the United States see religion's primary role as being “to help people be good" (Smith and Denton 2005:155; see also Smith and Snell 2009:148). The non-disclosing stimulus profile did not present any information indicating that the profile owner was not a good person, however, information that would have suggested that he or she was not religious. In addition, despite the fact that young people rarely talk about religion, they assume that their 
friends share their religious views (Smith and Snell 2009:153). In a majority-Christian country, the assumption that someone who does not disclose his/her religion is Christian may indeed seem reasonable. Since the stimulus profile did not contain any information that would contradict a Christian identity assumption, many respondents perceived the non-disclosing profile owner to be Christian. The prevalence of this assumed identity shows that the absence of Christian disclosure makes little difference in how one is evaluated.

Although they see religion's role as being to help people be good, young people also maintain that being good and moral does not require religion: "religion is a nonnecessary condition for achieving one of its primary functions" (Smith and Denton 2005:155). This is perhaps why the most religious respondents did not rate the extensively disclosing Christianthe person who may have come closest to voicing their own religious sentiments-in terms that were any less stereotypically negative than the person who did not say anything about his or her religion (Figure 1b). Once again, the presence and absence of Christian identification does not appear to lead to divergent evaluations.

Taken together, these observations suggest that nominal Christian disclosure is not that salient of an identity marker for young adults in the United States. It seems that it is just as fine not to say anything about being Christian as it is to identify as one. Even without saying anything, one is likely presumed to be Christian. Consequently, nominal Christian self-disclosure is a socially acceptable way of presenting oneself. But this general impotence of nominal Christian identification to affect distinct impressions may also be a factor discouraging Christian self-disclosure in online profiles.

\section{Limitations}


Religiosity is correlated with some demographic variables, such as age and education (e.g., Wuthnow 2007), for which this study did not control. The religious norms of the experiment's geographic setting may further limit generalizability. A majority of the population in the southern United States identifies as Christian, which is not true of all other U.S. regions (Kosmin and Keysar 2009), or of other industrialized countries (Bertelsmann Stiftung 2009). It is likely that the nominally disclosing Christian, for instance, would not have been evaluated as neutrally if the study was conducted elsewhere.

Future studies should consider same-gender and cross-gender designs. The self-reported attention measure should be validated by a series of objective memory recall questions. The sequence in which the dependent variable scales are administered should be rotated to account for potential order effects (Feldman and Lynch 1988).

Implications for future research

Disclosure effects. Comparative work should assess the differences associated with disclosures of such distinct identities, such as race, political views, sexual orientation, or sports team fandom (e.g., Tanis and Postmes 2003). Results would indicate how strong of an identity cue Christianity, or religion more broadly, is, relative other social identities.

More nuanced manipulations of Christian disclosure should be examined. Research may explore the threshold at which disclosure frequency makes a significant difference in impressions. Such a threshold would likely depend on the particular characteristics disclosed. Endorsement of a religious musical group, for instance, would likely be a more salient cue for young adults than affinity for an inspirational writer.

Differences in impressions of individuals representing theologically idiosyncratic Christian traditions (e.g., evangelical vs. mainline Protestant; Catholic vs. Protestant). Whether 
audiences distinguish between different manifestations of Christianity would constitute a primary operational hurdle. Recent work on religious literacy suggests that this study's respondents would likely not perceive such distinctions (Prothero 2007).

The finding that individuals who did not identify religiously were assumed to be Christian suggests research directed at determining the non-religious disclosures that promote, or detract from, the assumption of Christian identity. Such work would potentially establish an inventory of characteristics that are stereotypically associated with Christianity.

Beyond Christianity, there are compelling reasons to ascertain whether other religious or nonreligious identities prompt comparable differences in impressions. Disclosures of Mormon, Muslim, or atheist identities might elicit ambiguous, if not negative, impressions (Edgell, Gerteis, and Hartmann 2006; Panagopolous 2006; Saad 2007). Research on visible and invisible stigmatized identities such as mental illness, sexual orientation, and obesity has cataloged a considerable amount of data on the precursors and consequences of stigmatization (e.g., Abrams, Hogg, and Marques, 2005; Heatherton et al. 2000). It is worthwhile to assess, using impressions research, whether some religious identities are being stigmatized in contemporary society.

Ethnographic work should catalog how negative impressions of religious and other identity disclosures manifest themselves online, and what repercussions such disclosures might have on offline interactions. Deeper understanding of specific attributes and contextual details of such instances would inform further empirical investigations of social perceptions and psychological mechanisms that contribute to such effects.

Finally, research should examine the motives for respondents' positive and negative evaluations. It is unclear, for instance, if highly religious respondents liked the extensively disclosing Christian because this individual was like them, or because they admired this 
Christian's "witnessing” behavior. Studies examining more precisely the cognitive associations triggered by specific religious disclosures would contribute to a broader understanding of what it means to be religious in contemporary society.

Technology effects. It is worthwhile to consider whether the effects of online religious disclosures are more intense than in-person impressions (Hancock and Dunham 2001). A study focused on a marginalized identity (e.g., Muslim) testing differences between online and offline disclosures would potentially demonstrate particularly stark effects of online disclosure.

This study's stimuli were nearly exclusively textual, a rarity in today's online environment. Christian self-disclosures presented graphically, via audio, or via video, would likely positively affect the social presence of these communications as well as the resulting impressions (Short, Williams, and Christie 1976).

Online impressions are based on the totality of messages presented in their profiles (Walther et al. 2008). Future work in this area should measure how religious disclosures interact with potentially congruent and incongruent self- and other-generated messages. Perceptions that a Christian profile owner is conservative would likely be strengthened by a message endorsing a conservative social issue, for instance, and reactions would likely be more ambiguous if the message reflected a position or behavior generally not associated with Christianity.

\section{Summary}

This study was sparked by concerns that Christians' religious disclosures online may engender negative reactions and found some support for this claim. There is little evidence for a direct link between Christian disclosure and negative impressions, although extensive Christian disclosure leads to negative impressions among the least religious. Nominal Christian disclosure 
is generally perceived neutrally, likely because a nominal Christian identity tends to be assumed even when no Christian disclosure is made.

Perceptions of extensively disclosing Christians matched the outcomes predicted by principles of homophily and social identity theory. The expected nature of the effects found here does not diminish this study's contribution to the general understanding of religion's place in present-day society, and more specifically, in technology-mediated relationships. The study addressed a particular concern identified by Christians who participate in online social networks. Some prior evidence suggested that even minimal Christian disclosure may result in negative reactions from many Internet users. Results, meanwhile, support a more nuanced, theoretically grounded view.

Increased reliance on technology-mediated relationships motivates better understanding of religion's effect on online impressions. Future work should build on the findings presented here to gauge the effects of a broader range of online religious self-disclosures, and how these compare to the effects of other identity cues as well as comparable offline presentations. 


\section{References}

Abrams, Dominic, Michael A. Hogg, and Marques, José M., eds. 2005. The social psychology of inclusion and exclusion. New York: Psychology Press.

Aiken, Leona S. and Stephen G. West. 1991. Multiple regression: Testing and interpreting interactions. Newbury Park, CA: Sage.

Altman, Irwin and Dalmas A. Taylor. 1973. Social penetration: The development of interpersonal relationships. New York: Holt, Rinehart and Winston.

Batson, C. Daniel, Patricia Schoenrade, and W. Larry Ventis. 1993. Religion and the individual: A social-psychological perspective. New York: Oxford University Press.

Berger, Peter L. 1967. The sacred canopy: Elements of a sociological theory of religion. New York: Doubleday.

Bertelsmann Stiftung (ed.). 2009. What the world believes: Analyses and commentary on the Religion Monitor 2008. Gütersloh, Germany: Bertelsmann Stiftung.

Biela, Adam, Wilbert J. McKeachie, Yi-Guang Lin, and James Lingoes, J. 1993. Judgment of ingroups and out-groups by members of three denominations in the United States and Poland. Journal of Psychology and Christianity 12(3):225-35.

Bobkowski, Piotr S. 2008. Self-disclosure of religious identity on Facebook. Gnovis 9(1):article 4. Retrieved 21 January 2009. Available at http://gnovisjournal.org/journal/selfdisclosure-religious-identity-facebook.

Bolce, Louis and Gerald De Maio. 1999. The anti-Christian fundamentalist factor in contemporary politics. Public Opinion Quarterly 63(1):508-42.

-----. 2008. A prejudice for the thinking classes: Media exposure, political sophistication, and the anti-Christian fundamentalist. American Politics Research 36(2):155-85. 
Brennan, Kathleen M., and Andrew S. London. 2001. Are religious people nice people? Religiosity, race, interview dynamics, and perceived cooperativeness. Sociological Inquiry 71(2):129-44.

Burgess, Ernest W. and Paul Wallin. 1943. Homogamy in social characteristics. The American Journal of Sociology 49(2):109-24.

Buss, David M. and Michael Barnes. 1986. Preferences in human mate selection. Journal of Personality and Social Psychology 50(3):559-70

Byrne, Donn. 1971. The attraction paradigm. New York: Academic Press.

Carter, Stephen L. 1993. The culture of disbelief: How American law and politics trivialize religious devotion. New York: Anchor Books.

Casanova, José. 2003. What is a public religion? In Religion returns to the public square: Faith and policy in America, edited by Hugh Heclo and Wilfred M. McClay, pp. 111-39. Washington, D.C.: Woodrow Wilson Center Press, and Baltimore, MD: The Johns Hopkins University Press.

Castelli, Elizabeth A. 2007. Persecution complexes: Identity politics and the "War on Christians." Differences: Journal of Feminist Cultural Studies 18(5):152-80.

Culnan, Mary J. and Lynne M. Markus. 1987. Information technologies. In Handbook of organizational communication: An interdisciplinary perspective, edited by Fredric M. Jablin, Linda L. Putnam, Karlene H. Roberts, and Lyman W. Porter, pp. 420-43. Newbury Park, CA: Sage.

Edgell, Penny, Joseph Gerteis, and Douglas Hartmann. 2006. Atheists as “other”: Moral boundaries and cultural membership in American society. American Sociological Review 71(2):211-34. 
Ellison, Christopher. 1992. Are religious people nice people? Evidence from the National Survey of Black Americans. Social Forces 71(2):411-30.

Feldman, Jack M. and John G. Lynch, Jr. 1988. Self-generated validity and other effects of measurement on belief, attitude, intention, and behavior. Journal of Applied Psychology 73(3):421-35.

Greene, Kathryn, Valerian J. Derlega, and Alicia Mathews. 2006. Self-disclosure in personal relationships. In The Cambridge Handbook of Personal Relationships, edited by Anita L. Vangelisti and Daniel Perlman, pp. 409-27. New York: Cambridge University Press.

Hancock, Jeffrey T. and Philip J. Dunham. 2001. Impression formation in computer-mediated communication revisited: An analysis of the breadth and intensity of impressions. Communication Research 28(3):325-47.

Heatherton, Todd F., Robert E. Kleck, Michelle R. Hebl, and Jay G. Hull, eds. 2000. The social psychology of stigma. New York: Guilford Press.

Hogg, Michael A. 2006. Social identity theory. In Contemporary social psychological theories, edited by Peter J. Burke, pp. 111-36. Stanford, CA: Stanford University Press.

Hout, Michael and Claude S. Fischer. 2002. Why more Americans have no religious preference: Politics and generations. American Sociological Review 67(2):165-90.

Hyers, Lauri L. and Conrad Hyers. 2008. Everyday discrimination experienced by conservative Christians at the secular university. Analysis of Social Issues and Public Policy 8(1):11337.

Irwin, Julie R. and Gary H. McClelland. 2001. Misleading heuristics and moderated multiple regression models. Journal of Marketing Research 38(1):100-09. 
Kalyanaraman, Sriram and S. Shyam Sundar. 2006. The psychological appeal of personalized content in web portals: Does customization affect attitudes and behavior? Journal of Communication 56(1):110-32.

-----. 2008. Impression formation effects in online mediated communication. In Mediated interpersonal communication, edited by Elly A. Konijn, Sonja Utz, Martin Tanis, and Susan B. Barnes, pp. 217-33. New York: Routledge.

Kenworthy, Jared B. 2003. Explaining the belief in God for self, in-group, and out-group targets. Journal for the Scientific Study of Religion 42(1):137-46.

Kinnaman, David and Gabe Lyons. 2007. unChristian: What a new generation really thinks about Christianity and why it matters. Grand Rapids, MI: Baker Books.

Kosmin, Barry A. and Ariela Keysar. 2009. American religious identification survey (ARIS 2009): Summary report. Hartford, CT: Trinity College.

Liu, Hugo. 2007. Social network profiles as taste performances. Journal of Computer-Mediated Communication 13(1):252-75.

Manago, Adriana M., Michael B. Graham, Patricia M. Greenfield, and Goldie Salimkhan. 2008. Self-presentation and gender on MySpace. Journal of Applied Developmental Psychology 29(6):446-58.

Markus, Hazel and Paula Nurius. 1986. Possible selves. American Psychologist 41(9):954-69.

McPherson, Miller, Lynn Smith-Lovin, and James M. Cook. 2001. Birds of a feather: Homophily in social networks. Annual Review of Sociology 27:415-44.

Morgan, S. Philip. 1983. A research note on religion and morality: Are religious people nice people? Social Forces 61(3):683-92. 
Panagopolous, Costas. 2006. Arab and Muslim Americans and Islam in the aftermath of 9/11. Public Opinion Quarterly 70(4):608-24.

Pempek, Tiffany A., Yevdokiya A. Yermolayeva, and Sandra L. Calvert. 2009. College students' social networking experiences on Facebook. Journal of Applied Developmental Psychology 30(3):227-38.

Plante, Thoms G., Charlotte L. Vallaeys, Allen C. Sherman, and Kenneth A. Wallston. 2002. The development of a brief version of the Santa Clara strength of religious faith questionnaire. Pastoral Psychology 50(5):359-68.

Postmes, Tom, Russell Spears, and Martin Lea. 1998. Breaching or building social boundaries? SIDE-effects of computer-mediated communication. Communication Research 25(6):689-715.

Prothero, Stephen. 2007. Religious literacy: What every American needs to know-and doesn't. New York: HarperOne.

Saad, Lydia. 2007. Percentage unwilling to vote for a Mormon holds steady. Gallup Poll Briefing. December 11. Retrieved 23 April 2009. Available at http://www.gallup.com/ poll/103150/percentage-unwilling-vote-mormon-holds-steady.aspx.

Saroglou, Vassilis, Isabelle Pichon, Laurence Trompette, Marijke Verschueren, and Rebecca Dernelle. 2005. Prosocial behavior and religion: New evidence based on projective measures and peer ratings. Journal for the Scientific Study of Religion 44(3):323-48.

Sherkat, Darren E. 2004. Religious intermarriage in the United States: Trends, patterns, and predictors. Social Science Research 33(4):606-25.

Short, John, Ederyn Williams, and Bruce Christie. 1976. The social psychology of telecommunications. London: John Wiley. 
Smith, Christian with Melinda L. Denton. 2005. Soul searching: The religious and spiritual lives of American teenagers. New York: Oxford University Press.

Smith, Christian with Patricia Snell. 2009. Souls in transition: The religious \& spiritual lives of emerging adults. New York: Oxford University Press.

Storch, Eric A., Jonathan W. Roberti, Daniel M. Bagner, Adam B. Lewin, Audrey L.

Baumeister, and Gary R. Geffken. 2004a. Further psychometric properties of the Santa Clara strength of religious faith questionnaire - short-form. Journal of Psychology and Christianity 23(1):51-53.

Storch, Eric A., Jonathan W. Roberti, Erica Bravata, and Jason B. Storch. 2004b. Psychometric investigation of the Santa Clara strength of religious faith questionnaire - short-form. Pastoral Psychology 52(6):479-84.

Taylor, Dalmas A. and Irwin Altman. 1966. Intimacy-scaled stimuli for use in studies of interpersonal relationships. Research Report No. 9. Bethesda, MD: Naval Medical Research Institute.

Tanis, Martin and Tom Postmes. 2003. Social cues and impression formation in CMC. Journal of Communication 53(4):676-93.

Walther, Joseph. B. 1996. Computer-mediated communication: Impersonal, interpersonal, and hyperpersonal interaction. Communication Research 23(1):3-43.

Walther, Joseph B. and Judee K. Burgoon. 1992. Relational communication in computermediated interaction. Human Communication Research 19(1):50-88.

Walther, Joseph. B., Brandon Van Der Heide, Sang-Yeon Kim, David Westerman, and Stephanie Tom Tong. 2008. The role of friends' appearance and behavior on evaluations 
of individuals on Facebook: Are we known by the company we keep? Human Communication Research 34(1):28-49.

Wheeless, Lawrence R. and Janis Grotz. 1976. Conceptualization and measurement of reported self-disclosure. Human Communication Research 2(4):338-46.

Wuthnow, Robert. 2007. After the Baby Boomers: How the twenty-and thirty-somethings are shaping the future of American religion. Princeton, NJ: Princeton University Press. 
Table 1.

Summary of regression analyses for variables predicting evaluation of profile owner as likeable

\begin{tabular}{|c|c|c|c|c|c|c|c|c|c|c|c|c|}
\hline \multirow[b]{2}{*}{ Variable } & \multicolumn{4}{|c|}{ Model 1} & \multicolumn{4}{|c|}{ Model 2} & \multicolumn{4}{|c|}{ Model 3} \\
\hline & $B$ & $S E B$ & $\beta$ & & $B$ & $S E B$ & $\beta$ & & $B$ & $S E B$ & $\beta$ & \\
\hline Respondent gender (fem.) & .12 & .16 & .05 & & -.03 & .16 & -.01 & & -.02 & .16 & -.01 & \\
\hline Profile owner photo & .16 & .15 & .07 & & .19 & .15 & .08 & & .13 & .14 & .05 & \\
\hline Profile owner is talkative & .08 & .05 & .11 & & .05 & .05 & .08 & & .04 & .05 & .06 & \\
\hline Respondent attention & .25 & .06 & .26 & $* * *$ & .24 & .05 & .25 & $* * *$ & .21 & .06 & .22 & $* * *$ \\
\hline Nominal disclosure & -.22 & .18 & -.09 & & -.25 & .17 & -.10 & & -.23 & .17 & -.09 & \\
\hline Extensive disclosure & .45 & .18 & .17 & $*$ & .39 & .17 & .15 & $*$ & .38 & .17 & .15 & $*$ \\
\hline Respondent religiosity & & & & & .16 & .04 & .26 & $* * *$ & .04 & .06 & .07 & \\
\hline Nominal $\times$ Religiosity & & & & & & & & & .05 & .09 & .04 & \\
\hline Extensive $\times$ Religiosity & & & & & & & & & .30 & .09 & .29 & $* *$ \\
\hline$R^{2}$ & & & .16 & & & & .21 & & & & .26 & \\
\hline$N$ & & & 233 & & & & 233 & & & & 233 & \\
\hline
\end{tabular}

Note: $* * * p<.001, * * p<.01, * p<.05$. 
Table 2.

Summary of regression analyses for variables predicting evaluation of profile owner as romantically desirable

\begin{tabular}{|c|c|c|c|c|c|c|c|c|c|c|c|c|}
\hline \multirow[b]{2}{*}{ Variable } & \multicolumn{4}{|c|}{ Model 4} & \multicolumn{4}{|c|}{ Model 5} & \multicolumn{4}{|c|}{ Model 6} \\
\hline & $B$ & $S E B$ & $\beta$ & & $B$ & $S E B$ & $\beta$ & & $B$ & $S E B$ & $\beta$ & \\
\hline Respondent gender (fem.) & -.03 & .21 & -.01 & & -.11 & .21 & -.04 & & -.09 & .21 & -.03 & \\
\hline Profile owner photo & .00 & .19 & .00 & & .02 & .19 & .01 & & -.06 & .19 & -.02 & \\
\hline Profile owner is talkative & .11 & .06 & .13 & & .10 & .06 & .11 & & .08 & .06 & .09 & \\
\hline Respondent attention & .25 & .08 & .22 & $* *$ & .24 & .08 & .21 & $* *$ & .21 & .08 & .18 & $* *$ \\
\hline Nominal disclosure & -.50 & .23 & -.16 & $*$ & -.51 & .23 & -.16 & $*$ & -.49 & .23 & -.16 & $*$ \\
\hline Extensive disclosure & -.09 & .23 & -.03 & & -.12 & .23 & -.04 & & -.13 & .23 & -.04 & \\
\hline Respondent religiosity & & & & & .09 & .05 & .12 & & -.08 & .08 & -.11 & \\
\hline Nominal $\times$ Religiosity & & & & & & & & & .12 & .12 & .09 & \\
\hline Extensive $\times$ Religiosity & & & & & & & & & .37 & .12 & .30 & $* *$ \\
\hline$R^{2}$ & & & .08 & & & & .09 & & & & .14 & \\
\hline$N$ & & & 228 & & & & 228 & & & & 228 & \\
\hline
\end{tabular}

Note: $* * * p<.001, * * p<.01, * p<.05$. 
Table 3.

Summary of regression analyses for variables predicting negatively stereotyped evaluation of profile owner

\begin{tabular}{|c|c|c|c|c|c|c|c|c|c|c|c|c|}
\hline \multirow[b]{2}{*}{ Variable } & \multicolumn{4}{|c|}{ Model 7} & \multicolumn{4}{|c|}{ Model 8} & \multicolumn{4}{|c|}{ Model 9} \\
\hline & $B$ & $S E B$ & $\beta$ & & $B$ & $S E B$ & $\beta$ & & $B$ & $S E B$ & $\beta$ & \\
\hline Respondent gender (fem.) & .13 & .15 & .06 & & .24 & .15 & .11 & & .27 & .14 & .13 & \\
\hline Profile owner photo & -.34 & .13 & -.16 & $*$ & -.36 & .13 & -.17 & $* *$ & -.32 & .13 & -.15 & $*$ \\
\hline Profile owner is talkative & -.13 & .04 & -.21 & $* *$ & -.12 & .04 & -.18 & $*$ & -.10 & .04 & -.17 & $*$ \\
\hline Respondent attention & -.17 & .05 & -.20 & $* *$ & -.16 & .05 & -.19 & $* *$ & -.15 & .05 & -.18 & $* *$ \\
\hline Nominal disclosure & .02 & .16 & .01 & & .04 & .16 & .02 & & .05 & .15 & .02 & \\
\hline Extensive disclosure & .26 & .16 & .12 & & .30 & .16 & .14 & & .33 & .15 & .15 & $*$ \\
\hline Respondent religiosity & & & & & -.12 & .04 & -.22 & $* *$ & -.15 & .06 & -.29 & $* *$ \\
\hline Nominal $\times$ Religiosity & & & & & & & & & .20 & .08 & .20 & * \\
\hline Extensive $\times$ Religiosity & & & & & & & & & -.08 & .08 & -.09 & \\
\hline$R^{2}$ & & & .12 & & & & .16 & & & & .21 & \\
\hline$N$ & & & 233 & & & & 233 & & & & 233 & \\
\hline
\end{tabular}

Note: $* * * p<.001, * * p<.01, * p<.05$. 
(a) Likeable

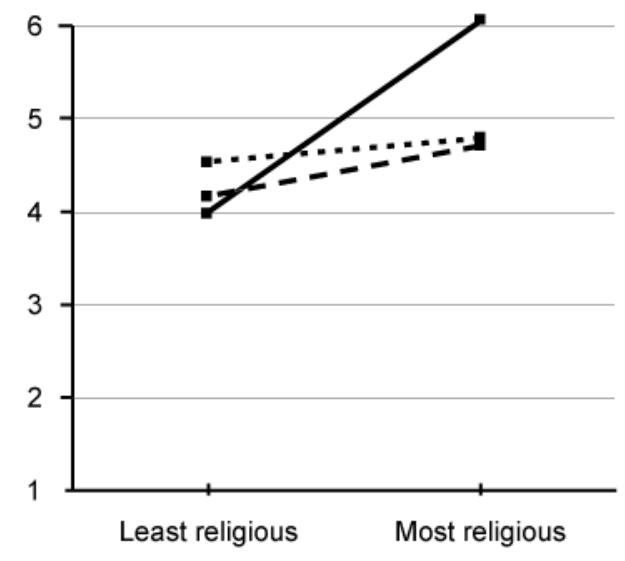

RESPONDENT (b) Romantically desirable

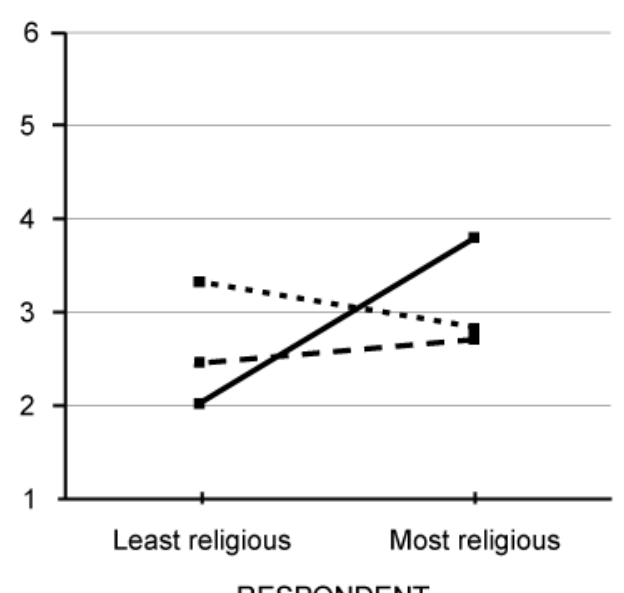

(c) Negative stereotype

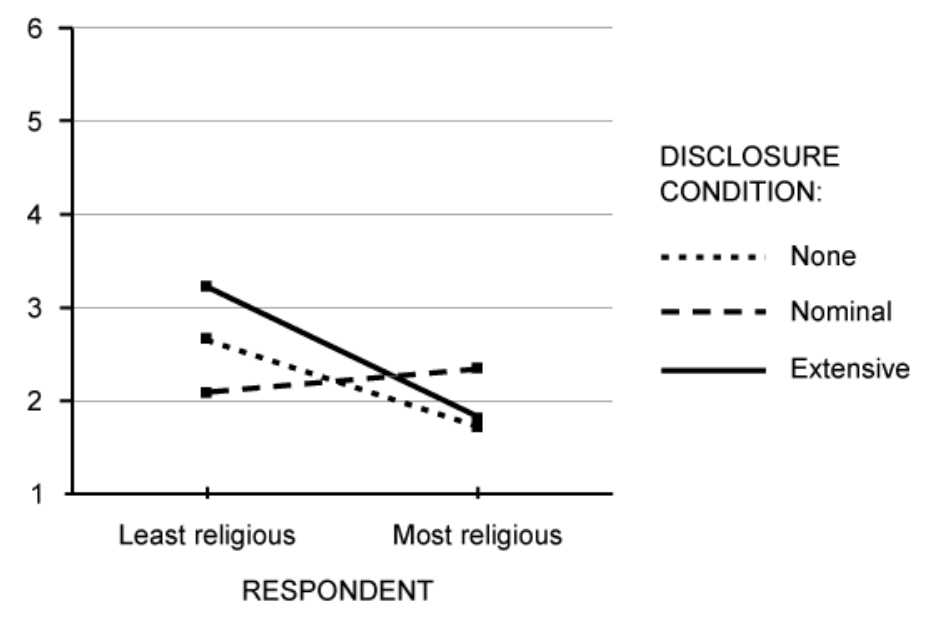

Figure 1. Profile owner (a) likeability, (b) romantic desirability, and (c) negative stereotype, as a function of respondent religiosity and disclosure frequency. 
Appendix 1

Comparison of nominal and extensive disclosure conditions ${ }^{1}$

\begin{tabular}{|c|c|c|c|}
\hline \multirow{2}{*}{\multicolumn{2}{|c|}{ Profile component }} & \multicolumn{2}{|c|}{ Disclosure condition } \\
\hline & & Nominal & Extensive \\
\hline \multirow{7}{*}{ Who is Sam } & Gender: & Depends on respondent gender & Depends on respondent gender \\
\hline & Age: & 20 & 20 \\
\hline & Ethnicity: & White & White \\
\hline & Hometown: & Charlotte, N.C. & Charlotte, N.C. \\
\hline & Orientation: & Straight & Straight \\
\hline & Status: & Single & Single \\
\hline & Religion: & Christian & Christian \\
\hline \multirow{4}{*}{$\begin{array}{l}\text { Sam's } \\
\text { school }\end{array}$} & College: & UNC ‘09 & UNC ‘09 \\
\hline & Major: & Communication Studies & Communication Studies \\
\hline & Best classes: & $\begin{array}{l}\text { Argument and debate, political } \\
\text { psychology }\end{array}$ & $\begin{array}{l}\text { Argument and debate, political } \\
\text { psychology }\end{array}$ \\
\hline & High school: & Providence '05 & Providence ‘05 \\
\hline \multirow{3}{*}{$\begin{array}{l}\text { In Sam's } \\
\text { own } \\
\text { words }\end{array}$} & \multirow{3}{*}{ About me: } & $\begin{array}{l}\text { Just your average Sam here, I } \\
\text { guess. I'm a student at UNC, } \\
\text { majoring in communication } \\
\text { studies. I don't know yet what } \\
\text { kind of a job that will lead to. I } \\
\text { like writing and I'm good at } \\
\text { interacting with people, so } \\
\text { something in the area of } \\
\text { communication, maybe. }\end{array}$ & $\begin{array}{l}\text { Just your average Sam here, I } \\
\text { guess. I'm a student at UNC, } \\
\text { majoring in communication } \\
\text { studies. I don't know yet what } \\
\text { kind of a job that will lead to. I } \\
\text { like writing and I'm good at } \\
\text { interacting with people, so } \\
\text { something in the area of } \\
\text { communication, maybe. }\end{array}$ \\
\hline & & $\begin{array}{l}\text { Although I have some thoughts } \\
\text { about the future, I still have a } \\
\text { while to figure it out. So for the } \\
\text { time being, I'm just trying my best } \\
\text { to experience life. }\end{array}$ & $\begin{array}{l}\text { Although I have some thoughts } \\
\text { about the future, I still have a } \\
\text { while to figure out God's plan for } \\
\text { me. So for the time being, I'm just } \\
\text { trying my best to love the Lord } \\
\text { and experience life. }\end{array}$ \\
\hline & & $\begin{array}{l}\text { I was born in Memphis, but when } \\
\text { my parents split up my mom } \\
\text { moved us to Charlotte. I've lived } \\
\text { there ever since and I try to go }\end{array}$ & $\begin{array}{l}\text { I was born in Memphis, but when } \\
\text { my parents split up my mom } \\
\text { moved us to Charlotte. I've lived } \\
\text { there ever since and I try to go }\end{array}$ \\
\hline
\end{tabular}

\footnotetext{
${ }^{1}$ Extra spacing in nominal disclosure column and underlined additional text in extensive disclosure column are provided here to facilitate line-by-line comparisons. Actual stimulus did not include these elements (see Appendix 2). With the exception of the "Religion: Christian" line, the nondisclosure condition was identical to the nominal disclosure condition.
} 
back regularly. I like the South, back regularly. I feel closest to but I like to visit new places, too. I God when I'm there. I like the really enjoyed a trip to New York South, but I like to visit new City that our band went on in high places too. I hope that whatever I school. I hope that whatever I do in the future will include traveling. do in the future will include traveling. Missionary work is not out of the question.

I am somewhat into sports, but not I am somewhat into sports, but not as much as others. I was on a as much as others. I was on a soccer team in middle school and high school and then I did some intramural stuff my freshman soccer team in middle school and high school and then I did some intramural stuff my freshman year. No I try to keep in shape by running and getting to the gym a couple of times a week. I cheer for Carolina, naturally. year. No I try to keep in shape by running and getting to the gym a couple of times a week. I cheer for Carolina, naturally.

As far as other things go ... I

As far as other things go ... I don't know ... I lead a pretty laid back life. I have an eclectic taste in music, I like to read a good book now and again, I like to have fun, and I'm easy to be friends with. I'm pretty outgoing and enjoy meeting new people.

don't know ... I lead a pretty laid back life. I have an eclectic taste in music, I like to read a good book now and again, I like to have fun, I praise and worship my Lord every single day, and I'm easy to be friends with. I'm pretty outgoing and enjoy meeting new people.

Into knowing more (I'm

Into knowing more (I'm presumptuous, I know)? Just holler. presumptuous, I know)? Just holler.

Running, reading, soccer, listening to music, traveling to new places, roadtrips, the beach, hiking, eating food that I've cooked, Carolina basketball, Caribou coffee, TCBY, parties, politics, peer counseling, reading the DTH, crosswords, sudoku, YouTube, waking up, going to the mall, recycling, photography, summer
Campus Crusade for Christ, running, reading, soccer, listening to music, traveling to new places, 24/7 prayer, roadtrips, the beach, hiking, eating food that I've cooked, Carolina basketball, Caribou coffee, TCBY, parties, politics, mission trips, peer counseling, reading the DTH, crosswords, sudoku, YouTube, waking up, going to the mall, recycling, photography, summer

Activities: I like hanging out with my friends I like hanging out with my friends 
and often crave chips and salsa. When I'm home, I take my ninety pound lab Hershey to the dog park. When I go to a sporting event, I tend to yell at the officials. I play solitaire on my iPod.

I'm guilty of getting a little competitive when it comes to board games and such. Anyone for a Scrabble or Pictionary tournament? Trivial Pursuit is my handicap, but I won't back away from a good challenge. and often crave chips and salsa. I lead a Bible study on campus. When I'm home, I take my ninety pound lab Hershey to the dog park. When I go to a sporting event, I tend to yell at the officials. I play solitaire on my iPod.

I'm guilty of getting a little competitive when it comes to board games and such. Anyone for a Scrabble or Pictionary tournament? Trivial Pursuit is my handicap, but like David facing Goliath, I won't back away from a good challenge.

Jeopardy, The Office, Lost, Colbert Report, Whose Line Is It Anyway?, Little Big World, TV: $\quad$ Mythbusters, 20/20, 60 Minutes, Grey's Anatomy, Scrubs, 24, House, The Price Is Right, the Weather Channel Jeopardy, The Office, Lost, Colbert Report, Whose Line Is It Anyway?, Little Big World, Mythbusters, 20/20, 60 Minutes, Grey's Anatomy, Scrubs, 24, House, The Price Is Right, the Weather Channel

Dead Poets' Society, Crash, Little The Passion of the Christ, Dead Miss Sunshine, The Godfather, Best In Show, Waiting for Goffman, Jurassic Park, Poets' Society, Crash, Little Miss Sunshine, The Godfather, Best In Show, Waiting for Goffman, Independence Day, Napoleon Dynamite, Pirates of the Jurassic Park, Independence Day, Napoleon Dynamite, Pirates of the Movies: $\quad$ Carribean, Juno, Little Mermaid, Carribean, Juno, Little Mermaid, Eternal Sunshine of the Spotless Mind, Darjeeling Express, Office Space, Saving Private Ryan, Remember the Titans, Mad Hot Ballroom, Anchorman, Ocean's Eleven, Mean Girls, Juno Eternal Sunshine of the Spotless Mind, Darjeeling Express, Office Space, Saving Private Ryan, Remember the Titans, Mad Hot Ballroom, Anchorman, Ocean's Eleven, Mean Girls, Juno

Dave Matthews Band, Coldplay, REM, vintage Michael Jackson, anything disco, David Grey,

Music: $\quad$ Depeche Mode, Duran Duran, Goo Goo Dolls, Third Eye Blind, Pat Green, Blink-182, John Casting Crowns, Switchfoot, Third Day, Mercy Me, Dave Matthews Band, Coldplay, REM, vintage Michael Jackson, anything disco, David Grey, Depeche Mode, Duran Duran, Goo Goo Mayer, The Beatles, Radiohead, Dolls, Third Eye Blind, Pat Green, 


\begin{tabular}{|c|c|c|c|}
\hline & & $\begin{array}{l}\text { Bob Dylan, James Taylor, Jack } \\
\text { Johnson, Tracy Chapman, Diana } \\
\text { Krall, plus your standard classical } \\
\text { and jazz stuff }\end{array}$ & $\begin{array}{l}\text { Blink-182, John Mayer, The } \\
\text { Beatles, Radiohead, Bob Dylan, } \\
\text { James Taylor, Jack Johnson, } \\
\text { Tracy Chapman, Diana Krall, plus } \\
\text { your standard classical and jazz } \\
\text { stuff }\end{array}$ \\
\hline & \multirow{4}{*}{ Quotes: } & $\begin{array}{l}\text { To thine own self be true. - } \\
\text { Shakespeare }\end{array}$ & $\begin{array}{l}\text { It is by grace you have been } \\
\text { saved. - Ephesians } 2: 6\end{array}$ \\
\hline & & $\begin{array}{l}\text { Only those who dare greatly can } \\
\text { ever achieve greatly. - Robert F. } \\
\text { Kennedy }\end{array}$ & $\begin{array}{l}\text { Trust in the Lord with all your } \\
\text { heart, lean not to your own } \\
\text { understanding, in all your ways } \\
\text { acknowledge Him and he will } \\
\text { direct your paths - Proverbs 3:5-6 }\end{array}$ \\
\hline & & & $\begin{array}{l}\text { To thine own self be true. - } \\
\text { Shakespeare }\end{array}$ \\
\hline & & & $\begin{array}{l}\text { Only those who dare greatly can } \\
\text { ever achieve greatly. - Robert F. } \\
\text { Kennedy }\end{array}$ \\
\hline \multirow{7}{*}{$\begin{array}{l}\text { Personal } \\
\text { details }\end{array}$} & Height: & $5 \mathrm{ft} 10$ in & $5 \mathrm{ft} 10$ in \\
\hline & Body type: & Average & Average \\
\hline & Best feature: & Smile & Smile \\
\hline & Zodiac sign: & Pieces & Pieces \\
\hline & Looking for: & Friendship, networking, dating & Friendship, networking, dating \\
\hline & Living with: & Roommates & Roommates \\
\hline & Kids: & None, maybe someday & None, maybe someday \\
\hline \multirow{10}{*}{$\begin{array}{l}\text { Random } \\
\text { stuff }\end{array}$} & Birthplace: & Memphis, Tenn. & Memphis, Tenn. \\
\hline & Heritage: & Irish, German, Italian, Slovak & Irish, German, Italian, Slovak \\
\hline & Shoe size: & 9.5 & 9.5 \\
\hline & Weakness: & Carbs & Carbs \\
\hline & Fears: & Having a job I don't love & Having a job I don't love \\
\hline & Goal: & $\begin{array}{l}\text { Having a good life with a nice } \\
\text { family }\end{array}$ & $\begin{array}{l}\text { Having a good life with a nice } \\
\text { family, and continuing to be } \\
\text { blessed by God }\end{array}$ \\
\hline & Bedtime: & Midnight, later on weekends & Midnight, later on weekends \\
\hline & Soft drink: & Diet coke & Diet coke \\
\hline & Fast food: & Taco Bell & Taco Bell \\
\hline & Ice cream: & Vanilla & Vanilla \\
\hline
\end{tabular}


Appendix 2

Stimulus profile example
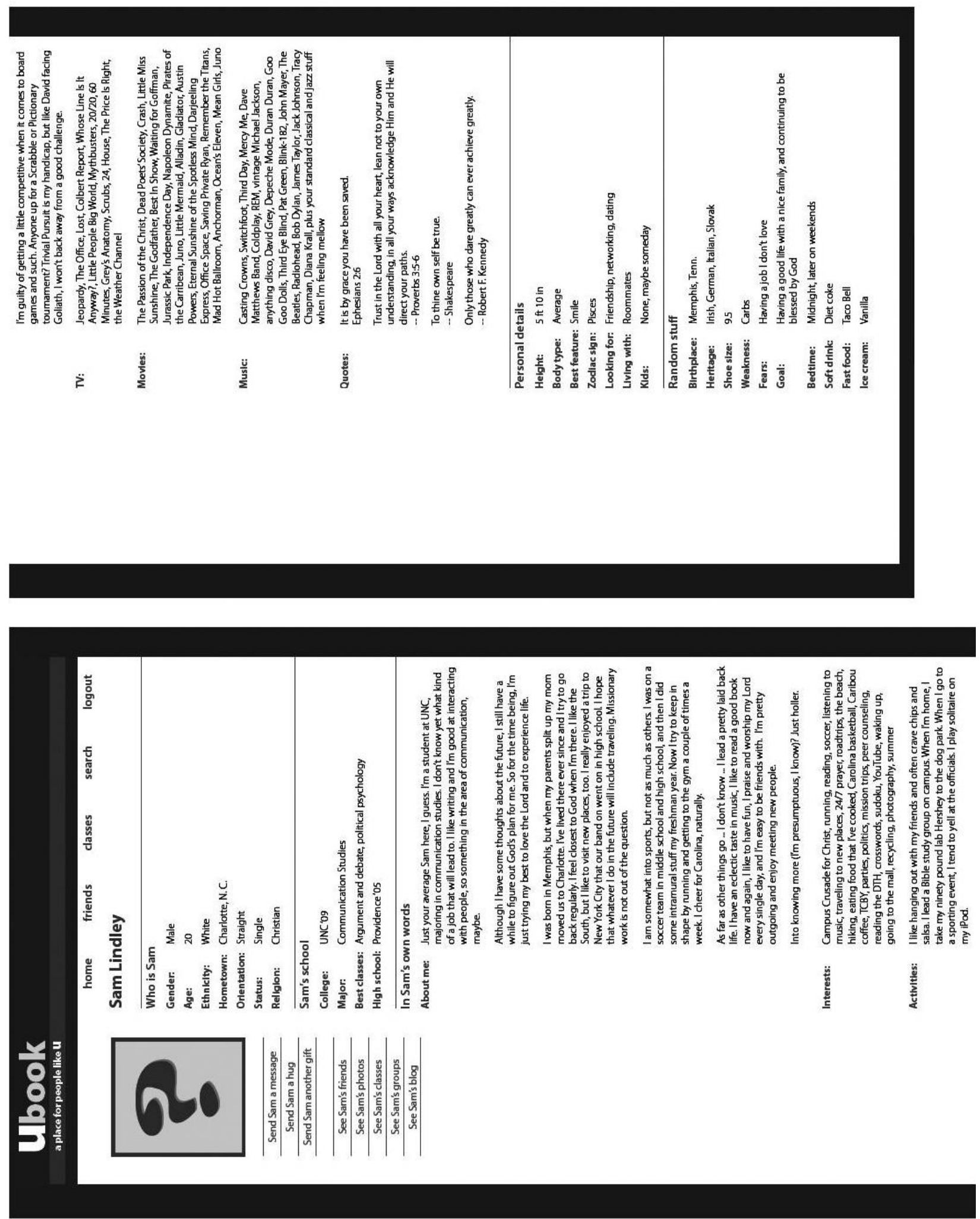